\title{
Determinants of health-related quality of life among human immunodeficiency virus positive (HIV-positive) patients at Ahmadu Bello University teaching hospital, Zaria, Nigeria- 2015
}

Bello Abdullahi Suleiman ${ }^{1,2^{*}}$, Mohammed Yahaya ${ }^{2,3}$, F. A. Olaniyan ${ }^{4}$, A. G. Sule ${ }^{4}$ and M. B. Sufiyan ${ }^{5}$

\begin{abstract}
Background: The advent of Highly Active Antiretroviral Therapy (HAART) is associated with improved clinical and laboratory outcomes resulting in prolonged life and well-being of people living with Human Immunodeficiency Virus (PLHIV). However, the needs for life-long therapy, medications' side effects and stigma have raised concerns about their quality of life (QOL). This study assessed the determinants of Health-related quality of life (HRQOL) among HIV-positive patients at Ahmadu Bello University Teaching Hospital (ABUTH) Zaria.

Methods: We conducted a cross-sectional study of 353 HIV-positive adults on HAART attending the HIV clinic of ABUTH, Zaria. The participants were recruited into the study using a systematic sampling technique. Data on sociodemographics, medical parameters, QOL and family functionality were collected using structured, intervieweradministered questionnaire. The World Health Organization (WHO) Quality of Life HIV short form instrument (WHOQOL-HIV BREF) item and Family APGAR tool were respectively used in assessing the QOL and family functionality of the participants. We performed univariate, bivariate and multivariate analysis.

Results: Mean age was 39.1( \pm 10.9$)$ years, 239 (67.7\%) were females, 208 (58.9\%) were Hausa-Fulani, 240 (68.2\%) married and up to 210 (59.4\%) had at least a secondary education. The overall mean scores on the scale of 4-20 for HRQOL were similar in three domains: environment domain 14.5( \pm 2.8$)$; social relationship 14.4( \pm 3.1$)$ and level of independence 14.4( \pm 2.5$)$. Lower scores were recorded in spirituality/religion/personal beliefs $12.3( \pm 4.3)$. Identified determinants of HRQOL were spousal HIV- positive status (AOR $\left.=3.37 ; \mathrm{Cl}_{1} 1.46-7.74\right)$ and high family function $(\mathrm{AOR}=2.57 ; \mathrm{Cl}: 1.51-4.39)$.

Conclusion: Having highly functional family and having HIV-positive partner were the major determinants of HRQOL. Routine family counselling and strengthening the HIV social-support network should be incorporated into the routine patients' care in HIV treatment centers.
\end{abstract}

Keywords: Health, Quality of life, Determinants, HIV/AIDS, HIV-positive

\footnotetext{
* Correspondence: bellonsaleehawa@gmail.com

'Department of Family Medicine, Federal Medical Centre Katsina, Katsina State, Nigeria

${ }^{2}$ Nigeria Field Epidemiology and Laboratory Training Program, Abuja, Nigeria

Full list of author information is available at the end of the article
}

(c) The Author(s). 2020 Open Access This article is licensed under a Creative Commons Attribution 4.0 International License, which permits use, sharing, adaptation, distribution and reproduction in any medium or format, as long as you give appropriate credit to the original author(s) and the source, provide a link to the Creative Commons licence, and indicate if changes were made. The images or other third party material in this article are included in the article's Creative Commons licence, unless indicated otherwise in a credit line to the material. If material is not included in the article's Creative Commons licence and your intended use is not permitted by statutory regulation or exceeds the permitted use, you will need to obtain permission directly from the copyright holder. To view a copy of this licence, visit http://creativecommons.org/licenses/by/4.0/. The Creative Commons Public Domain Dedication waiver (http://creativecommons.org/publicdomain/zero/1.0/) applies to the data made available in this article, unless otherwise stated in a credit line to the data. 


\section{Background}

Human Immunodeficiency Virus/Acquired Immune Deficiency Syndrome (HIV/AIDS) infection is a global pandemic, with cases reported from virtually every country. Worldwide, there is a decreasing trend of HIV infection and increase in survival of PLHIV. This is due to improved therapeutic and preventive measures. At the end of 2017, there were 36.9 million PLWHIV globally [1, 2]. AIDS-related deaths have been reduced by more than $51 \%$ since the peak in 2004 [1,2]. In the year 2017, some 940,000 people died from AIDS-related illnesses worldwide, compared to 1.4 million in 2010 and 1.9 million in $2004[1,2]$.

The problem of HIV/AIDS has been more debilitating in sub-Saharan Africa. In 2017, there were 19.6 million PLHIV; (53\%) in eastern and southern Africa, 6.1 million $(16 \%)$ in western and central Africa [1,2]. Nigeria is the most populous African country with the second largest burden of HIV/AIDS after South Africa [3, 4].

Studies have demonstrated the effectiveness of HAART in better clinical outcomes and the overall improvement of the QOL for PLHIV [5-7]. Even though with PLHIV being on life-long medications with the attendant consequences, this has brought out other issues that revolves around the psychosocial well being of these group of patients $[8,9]$. All these indicators of QOL are now been considered as important factors in the overall management of PLHIV $[8,9]$. HRQOL is a broad entity that denoted QOL based on patient's clinical outcome $[10,11]$. HRQOL further showcase the true definition of health as defined by the WHO $[10,11]$. The psychosocial well-being of patients with chronic diseases is further enhanced by evaluation of QOL for this category of patient $[9,11]$. Knowing the determinants of HRQOL would enable the patients, their families, healthcare providers as well as policy makers to devise relevant and holistic interventions to improve the general well-being and overall QOL of PLHIV.

We therefore assessed the determinants of HRQOL among HIV-positive adult patients attending HIV clinic of ABUTH, Zaria.

\section{Methods}

\section{Study design}

We conducted a hospital-based cross-sectional study at ABUTH Zaria, Kaduna state, Nigeria.

\section{Study setting}

The study was conducted in the HIV/PEPFAR clinic of ABUTH, Zaria. The hospital is a 500 bed capacity, established tertiary institution. It serves as a referral centre for primary and secondary health institutions in northern Nigeria.
The HIV clinic was established in 2006 and provides services for the diagnosis, treatment and prevention of HIV, in addition to free counselling and testing. It has the capacity to accommodate five hundred patients per clinic day and has several units, including adult (Antiretroviral Therapy) ART clinic, Paediatrics ART unit, the Prevention of Mother-to-Child transmission (PMTCT) unit, HIV/TB co-infection unit, Pharmacy unit and a PEPFAR accredited laboratory. The clinic runs daily from Monday to Friday and has a vibrant/ functional support group mainly supported by the social welfare department. The group helps members (PLHIV) in various ways such as continuous health education, mate-matching among the clients and financial empowerment of members for self-reliance through loans and trainings for small scale businesses.

\section{Study population}

The study participants comprised of all adult patients (18 years or more) on HAART therapy at the HIV clinic of ABUTH Zaria, Kaduna State, Nigeria.

\section{Inclusion and exclusion criteria}

All consented patients that attended the HIV clinic within the study period (March-May, 2015) were included. Patients that were severely ill, pregnant and those with psychiatric co-morbidities were excluded.

\section{Sample size estimation and sampling technique}

A sample size of 353 was used for our study based on an expected proportion $(p=50 \%)$ of adults on ART with good HRQOL [12]. Systematic sampling technique was used to recruit the subjects from the sampling frame using a calculated sampling interval of 13 . The first patient was randomly chosen out of the first 13 patients by balloting and the 7th patient was selected. Subsequently, the 20th, 33th, 46th and the $n^{\text {th }}$ were serially recruited until the required sample size was obtained.

\section{Data type and source}

An interviewer administered questionnaire was used in collecting the data. The structured questionnaire has four (4) main sections that include; the (socio-demographic variables), the medical parameters (clinical/laboratory), the adopted quality of life questionnaire [WHOQOL-HIV BREF] [9-18] and the APGAR SCORING system for assessing family functionality/support of the participants as sections one, two, three and four respectively. The WHOQOL-HIV BREF questionnaire has been widely used for QOL studies in PLWHIV, both locally and internationally [9-18].

The WHOQOL-HIV BREF is a 31 items tool distributed under 6 main domains comprising physical, social relationships, level of independence and spirituality 
domains with 4 items each. While the psychological and environmental domains have 5 and 8 items respectively. Each of the items was rated based on a 5-point Likert scale with 1 point as the lowest/negative perception and the highest/positive perception being the 5 points. The last 2 items in the tool measures overall perceived quality of life and general health perception. A mean of the overall scores of HRQOL domains was calculated and it was approximately 14.0, and this was used to categorize the subjects into two; high/good and low/poor QOL. A score of 14.0 and above signify high/good HRQOL while a score of less than 14.0 reflects poor/low HRQOL as used in the previous studies [12-14]. This method of categorization was adopted from previous (similar) studies done across the globe. The items in the tools were contextualized to the study area and translated to the local (Hausa) language [15-22]. Medical parameters were extracted from patients' medical records. Family functionality/support variable was measured using a 5item Family APGAR scale [15-22]. It was developed as a tool to measure a family member's perception of family functioning. A simple screening test which gives a rapid review of the components of family functioning in a mnemonic fashion similar to the APGAR evaluation of the newborn. APGAR stands for Adaptation, Partnership, Growth, Affection and Resolve. Each is tense based on individual perception. It is a Questionnaire based tool that is scored 0,1 and 2 respectively for "hardly ever", "some of the time" and "almost always" to determine the individual's perception of the respective issues represented by the acronym. Scores of 7-10 was considered as functional/supportive family while scores of 0-6 was considered dysfunctional/non-supporting family as used in previous studies [15-22].

\section{Data collection and analysis}

Questionnaires were administered by researcher and the assistants. It was pretested at a similar site providing HIV/AIDS care within the state (Giwa General Hospital ART Clinic).

We conducted a univariate analysis to describe the mean, standard deviation, median, range, frequency and proportions. The domain scores in WHOQOL-HIVBREF were scaled in positive direction with higher score indicating good quality of life. A mean score (14.0) of HRQOL was used to place the study participants into two; poor/low HRQOL for score $<14.0$ and high/good HRQOL for a score of 14.0 and above.

Bivariate analysis was carried out to evaluate the factors associated with HRQOL. However, variables which were found to be statistically significant at bivariate level and those with $p$-values $<0.10$ in the overall HRQOL were considered for multiple logistic regression analysis to identify the determinants of HRQOL.
Finally, multivariate logistic regression analysis was fit in. Using the stepwise approach, only the variables significant at $p<0.05$ were finally identified as determinants of HRQOL from all variables included in the logistic regression analysis. Adjusted odds ratios (AOR) of these significant variables with its corresponding 95\% confidence intervals were also reported.

\section{Results}

Most of the respondents 151 (42.8\%) were between the ages of 35-44 years with a mean age of $39.1( \pm 10.9)$ years. Most were females 239 (67.7\%) and Hausa-Fulani 208(58.9\%) by ethnicity. The respondents were mostly Muslims 222 (62.9\%) and 210 (59.4\%) of them had western education up to secondary and tertiary levels. Equally, $240(68.2 \%)$ of them were married and employed 266 (75.3\%). In this study, 304 (86.2\%) of the participants had HIV-positive partners (Table 1).

The mean scores of HRQOL of HIV/AIDS patients at ABUTH Zaria were highest in the environment $14.5( \pm$ 2.8 ), social relationship $14.4( \pm 3.1)$ and level of independence 14.4 $( \pm 2.5)$ domains. The lowest score was noted in the spirituality/religion/personal beliefs (SRPB) $12.3( \pm 4.3)$ domain. Higher mean scores of $15.2( \pm 3.9)$ and $15.0( \pm 3.9)$ were respectively recorded in the overall perception of HRQOL and general health perception (Table 2).

The proportion of respondents with high HRQOL was highest in the level of independence domain (69.4\%) followed by social relationship domain (65.7\%), environment domain (64.9\%), and psychological domain (56.9\%). The proportion of those with low HRQOL was highest in the spirituality/religion/personal belief domain (64.0\%) and physical domain (55.8\%). The proportion of respondent having High or Low HRQOL scores are shown in Fig. 1.

Bivariate analysis indicated a statistically significant relationship between HRQOL and marital status (OR: 1.81, CI: 1.12-2.94), educational status (OR: 1.68, CI: 1.072.63), spousal HIV status (OR: 0.35, CI: 0.16-0.77), disease stage (OR: 2.10, CI: 1.13-3.73) and family functionality of the patients (OR: 0.38 , CI: 0.23-0.61)) (Table 3).

Logistic regression analysis revealed partner's HIVpositive status (AOR $=3.37, \mathrm{CI}: 1.46-7.74)$ and high family function (AOR $=2.57, \mathrm{CI}: 1.51-4.39)$ as the only independent predictors/determinants of HRQOL (Table 4).

\section{Discussion}

In this study, majority of the participants were females signifying a high and disproportionate affectation of women by HIV. These findings were respectively consistent with findings in Ibadan (62.0\%), Kogi (62.7\%) and Sagamu (69.1\%) [15-17]. Women were more vulnerable to HIV infection than men during unprotected sexual intercourse, because of larger surface areas exposed to contact during intercourse and because the females are 
Table 1 Socio-demographic characteristics of HIV positive adult patients attending HIV Clinic at ABUTH Zaria, $2015(n=353)$

\begin{tabular}{|c|c|c|}
\hline Variables & Frequency (n) & Proportion (\%) \\
\hline \multicolumn{3}{|l|}{ Age (years) } \\
\hline$<25$ & 19 & 5.4 \\
\hline $25-34$ & 87 & 24.6 \\
\hline $35-44$ & 151 & 42.8 \\
\hline $45-54$ & 56 & 15.9 \\
\hline $55-64$ & 28 & 7.9 \\
\hline$\geq 65$ & 12 & 3.4 \\
\hline \multicolumn{3}{|l|}{ Sex } \\
\hline Male & 114 & 32.3 \\
\hline Female & 239 & 67.7 \\
\hline \multicolumn{3}{|l|}{ Ethnicity } \\
\hline Hausa-Fulani & 208 & 58.9 \\
\hline Yoruba & 13 & 3.7 \\
\hline Igbo & 20 & 5.7 \\
\hline${ }^{\mathrm{a} O t h e r s}$ & 112 & 31.7 \\
\hline \multicolumn{3}{|l|}{ Religion } \\
\hline Islam & 222 & 62.9 \\
\hline Christianity & 131 & 37.1 \\
\hline \multicolumn{3}{|l|}{ Level of Education } \\
\hline Non-formal & 18 & 5.1 \\
\hline Qur'anic/Islamiyya & 80 & 22.7 \\
\hline Primary & 45 & 12.7 \\
\hline Secondary & 87 & 24.6 \\
\hline Tertiary & 123 & 34.8 \\
\hline \multicolumn{3}{|l|}{ Marital status } \\
\hline Single & 31 & 8.8 \\
\hline Married & 241 & 68.2 \\
\hline Divorced & 37 & 10.5 \\
\hline Widow & 44 & 12.5 \\
\hline \multicolumn{3}{|l|}{ Employment status } \\
\hline Employed & 266 & 75.3 \\
\hline Unemployed & 61 & 17.3 \\
\hline Retired & 10 & 2.8 \\
\hline Student & 16 & 4.5 \\
\hline \multicolumn{3}{|l|}{ Spousal HIV status } \\
\hline Positive & 304 & 86.2 \\
\hline Negative & 49 & 13.8 \\
\hline \multicolumn{3}{|c|}{ Children's HIV status ( $n=322$ ) } \\
\hline Positive & 34 & 10.6 \\
\hline Negative & 288 & 89.4 \\
\hline
\end{tabular}

aOthers: Bajju, Kataf, Jaba, Tiv, Idoma, Igala, Nupe
Table 2 Mean Scores of HRQOL of HIV positive adult patients attending HIV clinic at ABUTH Zaria by Domains, $2015(n=353)$

\begin{tabular}{lll}
\hline HRQOL domains & Mean \pm SD & Minimum-Maximum \\
\hline Physical & $13.3( \pm 2.6)$ & $4-20$ \\
Psychological & $13.9( \pm 2.4)$ & $4-20$ \\
Level of Independence & $14.4( \pm 2.5)$ & $4-20$ \\
Social relationship & $14.4( \pm 3.1)$ & $4-20$ \\
Environment & $14.5( \pm 2.8)$ & $4-20$ \\
Spirituality/religion/belief & $12.3( \pm 4.3)$ & $4-20$ \\
Overall perception of HRQOL & $15.2( \pm 3.9)$ & $4-20$ \\
Overall General health perception & $15.0( \pm 3.9)$ & $4-20$
\end{tabular}

the recipient of infected semen, as well as possible micro trauma in their genital tract during sexual activity. Likely explanation could also be due to high levels of polygamy, early marriage, early sexual debut, female genital mutilation and low girl child education in the study environment.

We found few participants with post-secondary education and this was far less compared to the findings in Osogbo and China respectively, where up to 65.4 and $44 \%$ had post-secondary education $[18,23]$. This disparity may be due to low literacy level, low socio-economic status, high drop-out rate especially due to early marriage and low girl child education in the study area.

The study revealed that most of the subjects had HIVpositive partners and only one-tenth of them had HIVpositive children. Possible explanations could be due to increased number of marriages (mate-matching) among the HIV-postive patients facilitated by the HIV-support group in the facilty. Furthermore, scaled up preventive programs especially the prevention of mother-to-child transmission (PMTCT) services may be responsible for the low number of HIV-positive children.

Our study revealed higher mean scores of HRQOL in the environment domain. This was followed by the social relationship domain and then the level of independence domain. Lower mean scores were recorded in the psychological and physical domains. The spirituality/religion/personal belief domain had the lowest score. These findings were contrary to similar study from Kogi state, north-central Nigeria, in which the participants reported better QOL scores in the psychological, physical and spirituality domains, but lower scores in the environment and social domains [16]. Folasire in Ibadan reported higher mean scores in the physical, psychological and environment domains and lower scores in the social domain [15]. Our findings were in congruence with report from Henan- province, China where higher mean scores were recorded in the social and environment domains followed by the psychological domains [23]. In this study, the high domain scores recorded in the environment, social and level of independence reflect on the 


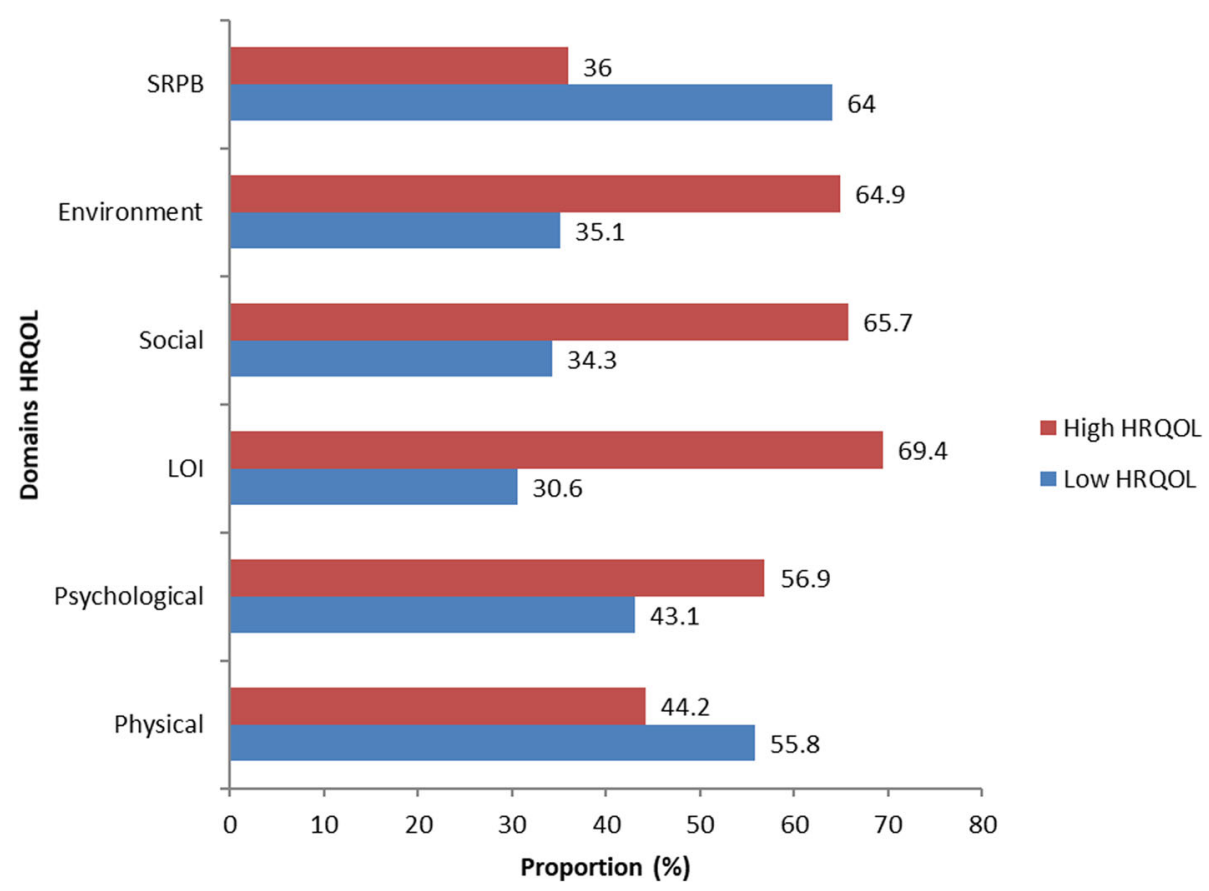

Fig. 1 Proportion of HIV positive adult patients attending HIV clinic at ABUTH Zaria with High or Low HRQOL per domains, 2015 ( $n=353)$

quality of care offered to these patients. Similarly factors like reduced stigma, non-discrimination, and increased acceptability in the community as well as good social support networks and other clinical interventions such as on-going psychotherapy might have played a role in improving the quality of life of these patients particularly in these domains [24]. Generally, in a country like Nigeria, it has been perceived that people tend to be more spiritual and religious only when confronted with issues that are beyond them [15]. The findings in this study did not agree with this belief. Lowest mean scores in the spirituality/religion/personal belief domains may be due to the wrong religious perception of HIV infection in the study area. A study on the influence of religious beliefs on HIV stigma, disclosure, and treatment attitudes in Tanzania indicated that shame-related HIV stigma is strongly associated with religious beliefs such as the belief that HIV is a punishment from God or that PLWHIV have not followed the word of God [25]. Similarly, in this study environment, people see HIV/AIDS patients as sexually promiscuous that go against the teachings of their religion. These may contribute to the patients' non-disclosure of their status due to fear of blames and discrimination, and fear of their future or even death [11].

In this study, more than half of participants had high HRQOL scores in the environment, social, level of independence and psychological domains. This is an inverse picture of the Bangladesh study [14]. The highest proportion of individuals had low HRQOL in the physical and spirituality/religion domains suggesting the severest impact of HIV extended across physical and spirit$\mathrm{ual} /$ religious aspect of HRQOL. This is expected as people with HIV/AIDS often experience physical inability, derogation, stigmatization, discrimination and marginalization [24].

This study also identified that couples with HIVpositive partners have better HRQOL compared to those with HIV-negative partners. A significant relationship was found between partners' HIV status and HRQOL. This is contrary to the report from China on a study of QOL in sero-discordant couples [23]. It can be explained by the kind of support, accommodation and care the patients enjoy from their fellow HIV-positive partners without fear of blames, stigma or discrimination. Similarly, regular clinic attendance and participation in the support group activities is more in participants with positive partners.

Our study noted asymptomatic patients with less severe disease and no co-morbidity to have higher/better HRQOL scores compared to their symptomatic counterparts. This was similar to earlier studies in which significant differences in HRQOL scores were observed between patients who were asymptomatic, symptomatic, as well as those with AIDS [15, 23, 26]. Akinboro and colleagues reported a significant relationship between HRQOL and $\mathrm{CD}_{4}$ count, disease clinical stage, presence of TB co-morbidity and ART treatment in Osun [18]. Conversely, Sagamu study reported no relationship between HRQOL and all the patients' medical parameters 
Table 3 Socio-demographic characteristics, Medical parameters and HRQOL among HIV positive adult patients attending HIV clinic in ABUTH Zaria, $2015(n=353)$

\begin{tabular}{|c|c|c|c|c|}
\hline \multirow[t]{2}{*}{ Variables } & \multicolumn{2}{|l|}{ HRQOL } & \multirow[t]{2}{*}{$\mathrm{OR}(\mathrm{Cl})$} & \multirow[t]{2}{*}{ P-value } \\
\hline & High HRQOL n (\%) & Low HRQOL n (\%) & & \\
\hline \multicolumn{5}{|l|}{ Age (years) } \\
\hline$<35$ & $35(33.0)$ & $71(67.0)$ & $0.84(0.53-1.34)$ & 0.475 \\
\hline$\geq 35$ & $95(38.4)$ & $152(61.6)$ & & \\
\hline \multicolumn{5}{|l|}{ Sex } \\
\hline Male & $45(39.5)$ & $69(60.5)$ & $0.86(0.54-1.36)$ & 0.526 \\
\hline Female & $86(36.0)$ & $53(64.0)$ & & \\
\hline \multicolumn{5}{|l|}{ Religion } \\
\hline Islam & 79 (35.6) & $143(64.4)$ & $0.84(0.54-1.31)$ & 0.440 \\
\hline Christianity & $52(39.7)$ & $79(60.3)$ & & \\
\hline \multicolumn{5}{|l|}{ Marital status } \\
\hline Currently Married & $100(41.4)$ & $141(58.6)$ & $1.81(1.12-2.94)$ & 0.015 \\
\hline Not Married & $31(28.1)$ & $81(71.9)$ & & \\
\hline \multicolumn{5}{|l|}{ Educational status } \\
\hline Secondary/Tertiary & $88(41.9)$ & $122(58.1)$ & $1.68(1.07-2.63)$ & 0.024 \\
\hline Qur'anic/Primary/None & $43(30.1)$ & $100(69.9)$ & & \\
\hline \multicolumn{5}{|l|}{ Occupation } \\
\hline Employed & $102(38.4)$ & $164(61.7)$ & $1.20(0.74-2.07)$ & 0.401 \\
\hline Not Employed & $29(33.3)$ & $58(66.7)$ & & \\
\hline \multicolumn{5}{|l|}{ Spousal HIV status } \\
\hline Positive & $121(39.7)$ & $183(60.3)$ & $0.35(0.16-0.77)$ & 0.007 \\
\hline Negative & $9(18.6)$ & $40(81.4)$ & & \\
\hline \multicolumn{5}{|l|}{ Disease Stage } \\
\hline Not Advanced Disease & $114(40.1)$ & $170(59.9)$ & $2.10(1.13-3.73)$ & 0.017 \\
\hline Advanced Disease & $17(24.6)$ & $52(75.4)$ & & \\
\hline \multicolumn{5}{|l|}{ Comorbidities } \\
\hline Present & $7(24.1)$ & $22(75.9)$ & $0.271(0.06-1.23)$ & 0.070 \\
\hline Absent & $124(38.3)$ & $200(61.7)$ & & \\
\hline \multicolumn{5}{|l|}{ CD4 Count (cells $/ \mathrm{mm}^{3}$ ) } \\
\hline$<500$ & $72(34.0)$ & $140(66.0)$ & $0.71(0.46-1.11)$ & 0.133 \\
\hline$\geq 500$ & $59(41.8)$ & $82(58.2)$ & & \\
\hline \multicolumn{5}{|l|}{ HAART Regimen } \\
\hline First line & $111(39.1)$ & $173(60.9)$ & $1.60(0.89-2.79)$ & 0.119 \\
\hline Second line & $20(29.0)$ & $49(71.0)$ & & \\
\hline \multicolumn{5}{|c|}{ Duration on Therapy (years) } \\
\hline$<5$ & $29(30.5)$ & $66(69.5)$ & $0.65(0.39-1.08)$ & 0.097 \\
\hline$\geq 5$ & $88(41.1)$ & $126(58.9)$ & & \\
\hline \multicolumn{5}{|l|}{ Family Functionality } \\
\hline Functional Family & $101(44.9)$ & $124(55.1)$ & $0.38(0.23-0.61)$ & $<0.001$ \\
\hline Dysfunctional Family & $30(23.4)$ & $98(76.6)$ & & \\
\hline
\end{tabular}

[27]. The explanation of these findings is that those who are sick (advance disease) are burdened with severe symptoms of the disease, which in turn, impair their
HRQOL. It is believed that the occurrence of two severe diseases can impact negatively on the QOL of the patients [28]. 
Table 4 a Determinants of HRQOL among HIV positive adult patients attending HIV clinic at ABUTH Zaria, $2015(n=353)$

\begin{tabular}{|c|c|c|}
\hline Variables & $\mathrm{AOR}(\mathrm{Cl})$ & $\boldsymbol{p}$-value \\
\hline \multicolumn{3}{|l|}{ Age (Years) } \\
\hline $0-34$ & $1.06(063,1.78)$ & 0.820 \\
\hline$\geq 35$ & 1.00 & \\
\hline \multicolumn{3}{|l|}{ Sex } \\
\hline Male & $1.29(0.76,2.19)$ & 0.337 \\
\hline Female & 1.00 & \\
\hline \multicolumn{3}{|l|}{ Religion } \\
\hline Islam & $0.98(0.58,1.63)$ & 0.930 \\
\hline Christianity & 1.00 & \\
\hline \multicolumn{3}{|l|}{ Marital status } \\
\hline Married & $1.19(0.64,2.21)$ & 0.580 \\
\hline Not married & 1.00 & \\
\hline \multicolumn{3}{|l|}{ Educational status } \\
\hline Secondary/Tertiary & $1.20(0.69,2.11)$ & 0.520 \\
\hline Qur'anic/Primary/None & 1.00 & \\
\hline \multicolumn{3}{|l|}{ Occupation } \\
\hline Employed & $1.23(0.66,2.31)$ & 0.513 \\
\hline Not employed & 1.00 & \\
\hline \multicolumn{3}{|l|}{ Spousal HIV status } \\
\hline Positive & $b_{3.37}(1.46,7.74)$ & 0.004 \\
\hline Negative & 1.00 & \\
\hline \multicolumn{3}{|l|}{ Disease Stage } \\
\hline Not Advance Disease & $0.80(0.41,1.58)$ & 0.525 \\
\hline Advance Disease & 1.00 & \\
\hline \multicolumn{3}{|l|}{ Comorbidities } \\
\hline Present & $0.29(0.06,1.43)$ & 0.124 \\
\hline \multicolumn{3}{|l|}{ Absent } \\
\hline \multicolumn{3}{|l|}{ Family Functionality } \\
\hline Functional Family & ${ }^{b} 2.57(1.51,4.39)$ & $<0.001$ \\
\hline Dysfunctional Family & 1.00 & \\
\hline
\end{tabular}

${ }^{\mathrm{a}}$ Multivariate- logistic regression analysis. ${ }^{\mathrm{b}}$ Major determinants of HRQOL

Most of the participants with dysfunctional (non-supportive) family had low HRQOL. Several studies had reported the significance of family support in improving the HRQOL of HIV/AIDS patients [29-31]. Odili and colleagues in a similar study in Benin-Nigeria, had reported a significant difference observed in all domains among respondents with family support compared to those without family support [32]. A well-functioning supportive family could support the patient in many aspects such as physically, socially, psychologically, emotionally and even spiritually.

This study identified partners' HIV- positive status and high family function as independent predictors of HRQOL among HIV-positive adult patients attending
HIV clinic at ABUTH, Zaria. Many studies identified individuals that were married, in relationship or staying with an adult to have better HRQOL when compared to those that were separated, single or had lost their spouses [33-37]. It is well known that the family setting provides safety, security and financial support. Therefore, those who were living with their family will likely enjoy better social support, closer interpersonal relationship and satisfactory sexual activity which in turn impact positively on their HRQOL $[36,37]$. Several studies had highlighted the relevance of family/social support in determining the HRQOL of PLWHIV [29-32].

\section{Limitations}

As this study is cross-sectional one, it cannot establish causality of the associations between the outcome variable and independent variables. Inclusion of only HIVpositive patients on HAART is not likely to provide a true picture on the determinants of HRQOL among HIV positive patients, as the study was performed prior to Universal Test and Treat (UTT) recommendations adopted in Nigeria. Therefore, updated assessment in the context of UTT is needed to overcome this limitation.

\section{Conclusions}

The study identified married subjects, with secondary or tertiary level of education, HIV-positive partners, less severe disease and functional family to have better HRQOL. It also reported higher mean scores for HRQOL in the environment, level of independence and social domains with the lowest scores in the spiritual/religion/personal belief domain. The major predictors of HRQOL in this study were having HIV-positive partner and highly functional family. We therefore recommend routine family counselling and strengthening the HIV social-support network should be incorporated into the routine patients' care in HIV treatment centers.

\section{Abbreviations}

ART: Antiretroviral therapy; Cl: Confidence interval; ABUTH, Zaria: Ahmadu Bello University Teaching Hospital, Zaria; HAART: Highly active anti-retroviral therapy; HRQOL: Health related quality of life; PLHIV: People Living with HIV; QOL: Quality of life; WHO: World Health Organization; WHOQOLHIVBREF: World Health Organization quality of life of HIV specific instrument brief

\section{Acknowledgements}

The authors acknowledged the support of the following organizations and distinguished personalities for their kind support and guidance towards this work: Ahmadu Bello University Teaching Hospital Zaria (ABUTH) Zaria; Nigeria Field Epidemiology and Laboratory Training Program (NFELTP); Professor Junaid Kabir; Dr. (Mrs) Mabel Aworh - Ajumobi; Dr. Chukwuma

Umeokonkwo; Dr. Muhammad Shakir Balogun and Dr. Eniola Bamgboye.

\section{Authors' contributions}

SBA (Principal investigator): proposed, designed and implemented the study, did the analysis and write-up. OFA and SAG: Made substantial contributions to conception and design of the proposal, analysis and interpretation of data, 
critically edit and approved the final manuscript. MY and SMB: Made significant contributions in design, interpretation of data, involved in revising and approved the final manuscript. OFA, SMB and MY: Participated sufficiently in analysis and interpretation of data, involved in drafting the manuscript, critically edit and approved the final manuscript. All authors read and approved the final manuscript.

\section{Funding}

No funding was received in the conduct of this study.

\section{Availability of data and materials}

The collected data for this study are available at the hands of the corresponding author and the data are not shared to third party to maintain confidentiality of patients' data. Clinical, laboratory and ART data were collected through reviewing records from ART cards and individual follow-up records using a structured questionnaire.

\section{Ethics approval and consent to participate}

Ethical approval for this research was granted by the Ahmadu Bello University Teaching Hospital Zaria scientific and ethical review committee. Subjects were adequately informed about the study both verbally and in writing before signing their informed consent. Confidentiality of their responses was assured and observed throughout the study. No personal identifiers were used on data collection questionnaire and confidentiality was maintained.

\section{Consent for publication}

Not Applicable.

\section{Competing interests}

The authors declare that they have no competing interests.

\section{Author details}

'Department of Family Medicine, Federal Medical Centre Katsina, Katsina State, Nigeria. ${ }^{2}$ Nigeria Field Epidemiology and Laboratory Training Program, Abuja, Nigeria. ${ }^{3}$ Department of Medical Microbiology \& Parasitology, Usmanu Danfodiyo University, Sokoto, Nigeria. ${ }^{4}$ Department of Family Medicine, Ahmadu Bello University Teaching Hospital, Zaria, Nigeria. ${ }^{5}$ Department of Community Medicine, Ahmadu Bello University, Zaria, Nigeria.

\section{Received: 13 May 2019 Accepted: 6 April 2020}

\section{Published online: 19 April 2020}

\section{References}

1. The Henry J. Kaiser Family Foundation. The Global HIV/AIDS Epidemic [Internet]. 2018 Nov [cited 10 $10^{\text {th }}$ April, 2019]. Available from: https://www.kff. org/global-health-policy/fact-sheet/the-global-hivaids-epidemic/.

2. National Agency for the control of AIDS (NACA). Global aids response Country progress report Nigeria GARPR 2014. Abuja: 2014; 1-69.

3. UNAIDS. World AIDS day report 2014. UNAIDS; 2014. http:/www.unaids.org/ en/media/unaids/contentassets/documents/epidemiology/2012/gr2012/ JC2434_WorldAIDSday_results_en.pdf. (Accessed on 13 Jan 2015).

4. National Agency for the Control of AIDS (NACA), Federal Republic of Nigeria. Global AIDS Response Country Progress Report (GARPR). 2012. Available at www.unaids.org/en/dataanalysis/knowyourresponse/countryprogressreports/2 012/country/Nigeria.pdf. (Accessed on 13 Jan 2015).

5. Moore RD, Chaisson RE. Natural history of HIV infection in the era of combination antiretroviral therapy. AIDS. 1999;13(14):1933-42.

6. Fairall LR, Bachmann MO, Louwagie GM, Vuuren C, Chikobvu P, Steyn D, et al. Effectiveness of antiretroviral treatment in a south African program: a cohort study. Arch Intern Med. 2008;168(1):86-93.

7. Sow PS, Otieno LF, Bissagnene E, Bishai D, Colchero A, Durack DT, et al. Implementation of an antiretroviral access program for HIV-1-infected individuals in resource-limited settings: clinical results from 4 African countries. J Acquir Immune Defic Syndr. 2007;44(3):262-7.

8. Beard J, Feeley F, Rosen S. Economic and quality of life outcomes of antiretroviral therapy for HIV/AIDS in developing countries: a systematic literature review. AIDS Care. 2009;21(11):1343-56.

9. The World Health Organization. Quality of life assessment (WHOQOL): development and general psychometric properties. Soc Sci Med. 1998; 12(12):1569-85.
10. Bonomi AE, Patrick DL, Bushnell DM, Martin M. Validation of the United States' version of the World Health Organization quality of life (WHOQOL) instrument. J Clin Epidemiol. 2000;53(1):1-12.

11. Cunninghams WE, Crystal S, Bozzette S, Hays RD. The association of healthrelated quality of life with survival among persons with HIV infection in United States. J Gen Intern Med. 2005;20(1):21-7.

12. Yetnayet Abebe Weldsilase, Melaku Haile Likka, Tolossa Wakayo, and Mulusew Gerbaba, "Health-Related Quality of Life and Associated Factors among Women on Antiretroviral Therapy in Health Facilities of Jimma Town, Southwest Ethiopia," Advances in Public Health, vol. 2018, Article ID 5965343, 12 pages, 2018

13. Osei-Yeboah J, Owiredu WKA, Norgbe GK, Lokpo SY, Obirikorang C, Alote $A E$, et al. Quality of life of people living with HIV/AIDS in the ho municipality, Ghana: a cross-sectional Study. AIDS Res Treatment. 2017:1-7. https://doi.org/10.1155/2017/6806951.

14. Imam M, Karim M, Ferdous C, Akhter S. Health related quality of life among the people living with HIV. Bangladesh Med Res Counc Bull. 2011;37(1):1-6.

15. Folasire OF, Irabor AE, Folasire AM. Quality of life of people living with HIV and AIDS attending the antiretroviral clinic, university college hospital, Nigeria. African J Prim Heal Care Fam Med. 2012;4(1):1-8.

16. Fatiregun AA, Mofolorunsho KC, Osagbemi KG. Quality of life in people living with HIV/AIDS in Kogi state, Nigeria. Benin J Postgrad Med. 2009;11(1):21-7.

17. Motilewa OO, Ekanem US, Onayade A, Sule SS. A comparative study of health related-quality of life among HIV patients on pre-HAART and HAART in Uyo south-South Nigeria. J Antivir Antiretrovir. 2015;07(02):60-8.

18. Akinboro AO, Akinyemi SO, Olaitan PB, Raji AA, Popoola AA, Awoyemi OR, et al. Quality of life of Nigerians living with human immunodeficiency virus. Pan Afr Med J. 2014;18:1-11.

19. Smilkstein G. The family APGAR: a proposal for a family function test and its use by physicians. J Fam Pract. 1978;6(6):1231-9.

20. Smilkstein GA. The physician and family function assessment. Fam Syst Med. 1984;2(3):263-78.

21. Shapiro J, Neinstein B, Lawrence S, Rabinovitz S. The Family APGAR: Use of a simple family-functioning screening test with adolescents. Fam Syst Med 1987; 5(2):220-227.

22. Gardner W, Nutting PA, Kelleher KJ, Werner JJ, Farley T, Stewart L, et al. Does the family APGAR effectively measure family functioning? I Fam Pract. 2001;50(1):19-25.

23. Shan D, Ge Z, Ming S, Wang L, Sante M, He W, et al. Quality of life and related factors among HIV-positive spouses from serodiscordant couples under antiretroviral therapy in Henan Province, China. PLoS One. 2011;6(6): 25-35.

24. Liu C, Weber K, Robinson E, Hu Z, Jacobson LP, Gange SJ. Assessing the effect of HAART on changes in quality of life among HIV-infected women. AIDS Res Ther 2006; 3:6. https://doi.org/10.1186/1742-6405-3-6, PMCid: 1459186.

25. James Z, Young Y, Muze J, Melissa W, Jan O, Nathan T. Religion and HIV in Tanzania: influence of religious beliefs on HIV stigma, disclosure, and treatment attitudes. BMC Pub H. 2009;9:75.

26. Wig N, Lekshmi R, Pal H, Ahuja V, Mittal CM, Agarwal SK. The impact of HIV_ AIDS on the quality of life: a cross sectional study in North India. Indian J Med Sci. 2006;60(1):3-12.

27. Amoran OE, Sholeye AO, Salako AA, Fatungase OM. Determinants of self reported health related quality of life among people living with HIV / AIDS attending Clinic in a Tertiary Hospital in Sagamu, South-Western Nigeria. Bri J Appl Sci Tech. 2014;4(8):1296-308.

28. Deribew A, Tesfaye M, Hailmichael L. Tuberculosis and HIV co-infection: its impact on quality of life. Health Qual Life Outcomes. 2009;7:105.

29. Fairall LR, Bachmann MO, Louwagie GM, Vuuren C, Chikobvu P, Steyn D, et al. Effectiveness of antiretroviral treatment in a South African program: A cohort study. Arch Intern Med 2008 14; 168(1):86-93.

30. Louwagie GM, Bachmann MO, Meyer K, Booysen FR, Fairall RL, Heunis C Highly active antiretroviral treatment and health related quality of life in south African adults with human immunodeficiency virus infection: a crosssectional analytical study. BMC Public Health. 2007;7:244.

31. Adedimeji AA, Odutolu O. Care support and quality of life outcomes among persons living with HIV in the HAART era; Findings from Southwest Nigeria [homepage on the Internet]. No date Available from: http:// www.hsph. harvard.edu. [Accessed 4 May 2014].

32. Odili VU, Isibhakhomen BI, Usifon SF, Oparah AC. Determinants of quality of life of HIV/AIDS patients. West Afr J of Pharm. 2011;22(1):42-8. 
33. Lichtenstein B, Laska MK, Clair JM. Chronic sorrow in the HIV-positive patient: issues of race, gender, and social support. AIDS Patient Care STDs. 2002;16(1):27-38.

34. Aranda BN. Quality of life of the HIV- positive patients: implication and consequences. JANAAC. 2004;15(5):2017.

35. Ana María TH, Jorge PS, Mario MV, Rafael TM. Affectation Situation of HIV/ AIDS in Colombian Children, Health Management - Different Approaches and Solutions. 2011; Available from: http://www.intechopen.com/books/ health-management-different-approaches-and-solutions/affectationsituationof-hiv-aids-in-colombian-children.

36. Kovačević SB, Vuručić TV, Duvančić K, Maček M. Quality of life of HIVinfected persons in Croatia. Coll Antropol. 2006;30(2):79-84.

37. Abboud S, Noureddine S, Huijer HA-S, DeJong J, Mokhbat J. Quality of life in people living with HIV/AIDS in Lebanon. AIDS Care. 2010;22(6):687-96.

\section{Publisher's Note}

Springer Nature remains neutral with regard to jurisdictional claims in published maps and institutional affiliations.

Ready to submit your research? Choose BMC and benefit from:

- fast, convenient online submission

- thorough peer review by experienced researchers in your field

- rapid publication on acceptance

- support for research data, including large and complex data types

- gold Open Access which fosters wider collaboration and increased citations

- maximum visibility for your research: over $100 \mathrm{M}$ website views per year

At BMC, research is always in progress.

Learn more biomedcentral.com/submissions 